\title{
Pisanie o kobiecie a „pisanie kobiety” w twórczości Marii Krüger
}

\author{
Jędrych, K. (2017). Portret dziewczynki, dziewczyny i kobiety \\ w powieściach Marii Krüger. Katowice: Wydawnictwo UŚ.
}

\section{Abstrakt:}

W artykule recenzyjnym autorka poddaje analizie książkę Karoliny Jędrych zatytułowaną Portret dziewczynki, dziewczyny i kobiety w powieściach Marii Krüger (2017), która jest prekursorską monografią poświęconą twórczości tytułowej pisarki, zogniskowaną wokół precyzyjnie określonych zagadnień, dotyczących kreacji dziewczęcości i kobiecości prezentowanych z perspektywy krytyki feministycznej oraz gender studies. Autorka dochodzi do wniosku, że rozważania Jędrych przynoszą ciekawe i nowatorskie rozpoznania twórczości pisarki, a także wytyczają nowe kierunki badań nad tą twórczością lub twórczością piszących podobnie do Krüger, których proza skierowana do dziewcząt i kobiet wymaga rzetelnego opisu z perspektywy feminizmów. Wydaje się bowiem, że tylko krytyczne odczytania literatury skierowanej do dziewcząt, osadzone w nowych metodologiach, są w stanie dać jej drugie życie i wyjaśnić współczesnym czytelnikom/czytelniczkom fenomen dawnej popularności tego subgatunku.

\section{Słowa kluczowe:}

gender studies, herstoria, Karolina Jędrych, krytyka feministyczna, literatura dziecięca i młodzieżowa, Maria Krüger, powieść dla dziewcząt

* Katarzyna Slany - dr, pracuje w Instytucie Pedagogiki Przedszkolnej i Szkolnej Wydziału Pedagogicznego na Uniwersytecie Pedagogicznym im. KEN w Krakowie. Jej zainteresowania badawcze obejmują współczesną polską i zagraniczną literaturę dziecięcą i młodzieżową. Kontakt: katarzyna.slany@up.krakow.pl. 


\section{Writing about a Woman and 'Writing a Woman' in the Work of Maria Krüger}

\section{Jędrych, K. (2017). Portret dziewczynki, dziewczyny i kobiety w powieściach Marii Krüger. Katowice: Wydawnictwo UŚ.}

\section{Abstract:}

In the article, the author analyses the book written by Karolina Jędrych entitled Portret dziewczynki, dziewczyny i kobiety w powieściach Marii Krüger [The Image of a Little Girl, an Adolescent, and a Woman in the Novels of Maria Krüger] (2017), which is a forerunner monograph devoted to the works of the title writer, focused on precisely defined issues that concerns girls and women, presented from the perspective of feminist criticism and gender studies. The author concludes that Jędrych's monograph entails interesting and innovative recognition of Krüger's literature and sets new directions for research on these works or the works of authors writing similarly to Krüger, whose prose directed to girls and women requires a reliable description from the perspective of feminisms. It seems that only a critical reading of literature addressed to girls, embedded in new methodologies, can give it a second life and explain to contemporary readers the phenomenon of the former popularity of this genre.

\section{Key words:}

gender studies, herstory, Karolina Jędrych, feminist criticism, children's and young adult literature, Maria Krüger, novel for girls

K siążka Karoliny Jędrych (2017) zatytułowana Portret dziewczynki, dziewczyny $i$ kobiety $w$ powieściach Marii Krüger to prekursorska monografia poświęcona twórczości tytułowej pisarki, zogniskowana wokół precyzyjnie określonych zagadnień, które dotyczą kreacji dziewczęcości i kobiecości prezentowanych z perspektywy krytyki feministycznej oraz gender studies. Koncepcję interpretacyjną i metodologiczną pracy badaczka omawia we Wstępie, w którym przedstawia cel swoich badań: wielowymiarowe omówienie „bohaterek powieści [Marii Krüger], których wirtualnym odbiorcą jest dziewczyna lub kobieta oraz powieści, których główną bohaterką jest dziewczynka, dziewczyna i kobieta" (s. 10). Autorka poddaje analizie następujące utwory: Szkoła narzeczonych (Krüger, 1945), Godzina pąsowej róży (Krüger, 1960), Klimek i Klementynka (Krüger, 1962), Brygida (Krüger, 1970), Gorzkie wino (Krüger, 1975a), Petra (Bielińska, Krüger, 1957/1975b), Po prostu Lucynka P. (Krüger, 1980) oraz Odpowiednia dziewczyna (Krüger, 1988). Poza wspomnianym Wstępem monografia składa się z dwóch rozbitych na mniejsze studia rozdziałów: I. Tło portretu oraz II. Portrety, a także z Zakończenia poświęconego tropom biograficznym odnalezionym przez Jędrych w analizowanych utworach Krüger. 
Badaczka sytuuje część utworów (oprócz Brygidy i Gorzkiego wina, które postrzega jako powieści dla kobiet) w ramach subgatunku, jakim jest powieść dla dziewcząt. Jej wyznaczniki omawia, przywołując ustalenia znawczyń polskiej prozy dla nastolatek, takich jak Monika Graban-Pomirska (2006), Anna Kruszewska-Kudelska (1972), Elżbieta Kruszyńska (2009), Grażyna Lasoń-Kochańska (2012) i Małgorzata Wójcik-Dudek (2007, 2008). Jędrych za kluczową cechę utworów kierowanych do nastoletnich czytelniczek uważa kategorię wirtualnej odbiorczyni, która implikuje określony styl tych powieści oraz ich hermetyczny krąg czytelniczy, sprowadzony do reprezentantek płci żeńskiej. Autorka syntetyzuje najważniejsze informacje z zakresu omawianego subgatunku. Kreśli historyczną ścieżkę jego rozwoju od dwudziestolecia międzywojennego do końca XX wieku, w którym możemy zaobserwować „przejście od powieści dla dziewcząt do powieści dziewczęcej” (Jędrych, 2017, s. 22). Badaczka na zróżnicowanych przykładach zaczerpniętych z XX-wiecznej prozy młodzieżowej prezentuje interesujące zabiegi artystyczne, dzięki którym omawiane przejście staje się dostrzegalne. Autorka krótko omawia też krytyczne podejście do utworów sygnowanych płcią obecne w dyskursach feministycznych i gender studies.

Jędrych, co cenne i rzadkie wśród badaczek literatury dziecięcej i młodzieżowej, zaznacza, że perspektywa feministyczna, poszukiwanie herstorii oraz dekonstruowanie stereotypów kobiecości jest jej metodologicznie i tożsamościowo bliskie. Tę naukową deklarację podpiera autorytetem Krystyny Kłosińskiej (1999) i fascynacją jej przełomową dla polskiej krytyki feministycznej monografią Ciało, pożądanie, ubranie. O wczesnych powieściach Gabrieli Zapolskiej, która stała się dla autorki metodologiczną inspiracją podczas pisania opracowania o twórczości Krüger. Badaczka przystępnie wykłada ogólne założenia krytyki feministycznej oraz płci społeczno-kulturowej i nakreśla ich dotychczasowe zastosowanie $\mathrm{w}$ pracach naukowych poświęconych literaturze dla niedorosłych. Atutem rozważań na temat metodologii wykorzystanej w monografii jest odautorska potrzeba nicowania interpretowanego materiału literackiego przez pryzmat „ja” podmiotu badającego. Jędrych (2017) pisze:

[...] chciałabym spróbować przeczytać niektóre teksty Marii Krüger - te przeznaczone dla dorastających dziewcząt - ,jako dziewczyna”; odnaleźć w tych tekstach nie tylko „kobiecość", ale także „dziewczęcość", powrócić do wspomnień pierwszych odczytań Godziny pąsowej róży, Szkoły narzeczonych, Odpowiedniej dziewczyny czy Petry, z którymi to powieściami zetknęłam się jako nastolatka. Te oraz inne powieści dla dziewcząt (głównie autorstwa Lucy Maud Montgomery) były moimi pierwszymi samodzielnie i świadomie wybranymi lekturami [...] (s. 22). 
Badaczka z powodzeniem realizuje swoje założenie: udaje jej się wyjść poza ramy sztywnego podmiotu badawczego i, co niezwykle istotne dla współczesnej humanistyki, nowatorsko odczytywać utwory pisarki z uwzględnieniem indywidualnej perspektywy kobiecej.

W rozdziale pierwszym, zatytułowanym Tło portretu, autorka odwołuje się do teorii fantazmatu Marii Janion (1991) i topofilii Gastona Bachelarda (1960/1975), przystosowanych na grunt teorii literatury dziecięcej przez Alicję Baluch (2008). Przez ich pryzmat Jędrych ukazuje przestrzenie bezpieczne, swoiste „imaginacyjne mieszkania”, które często pozostają w sprzeczności z miejscami zamieszkiwanymi przez bohaterki w rzeczywistości, w dzieciństwie lub w młodości. Bezpieczeństwo i piękno wpisane w te imaginacyjne kobiece topofilie wyrasta $\mathrm{z}$ ich dziecięcych pragnień o dobrym domu i stanowi rodzaj wyobraźniowych wysp lub przylądków, do których można uciekać przed prozą życia. Badaczka poszukuje doświadczeń specyficznie kobiecych, obecnych zarówno w skali makro (historie wojenne), jak i mikro (zmysłowe picie kawy lub inne prozaiczne czynności, którym bohaterki nadają niemal epifaniczny sens). Jędrych bardzo sugestywnie odczytuje kobiecą mikrosferę w kontekście filozofii „krzątactwa” omawianej przez Jolantę Brach-Czainę (1992/1999) jako dowartościowanie kobiecych codziennych czynności, nadanie im wagi doznań niezwykłych; to one asekurują czytelnika/czytelniczkę przed his-toria za pomocą herstorii - są intymnymi impresjami z realnego i wyobraźniowego życia bohaterek, które składają się na mocno wybrzmiewające we współczesnych dyskursach posthumanizmu mikronarracje herstoryczne (Domańska, 1999). Co więcej, badaczka kreśli feministyczne tło dla konkretnych kobiecych portretów psychologicznych, uwzględniając XIX- i XX-wieczne realia społeczne, obyczajowe i kulturowe, w jakich dorastają i wychowują się bohaterki, pokazując, że pisarka budowała wyobrażenia kobiet zgodnie ze stereotypami kobiecości, ale potrafiła także obnażać dramaty kobiece, negatywne doświadczenia postaci wynikające $\mathrm{z}$ ról i sfer społecznych, w jakich funkcjonowały:

Gorzkie wino pokazuje, że piękna epoka wcale nie była taka piękna, jak w Godzinie... [pąsowej róży] odmalowała ją Krüger. Głęboko pod strojnymi sukniami, warstwami koszulek i halek, kryły się brudne gorsety. Pod wyrafinowanymi obyczajami zaś proste, a nawet prymitywne pragnienia. Pod szacunkiem dla rodziców - despotyczna władza matek nad córkami. Przełom wieków XIX i XX, oglądany niejako „od kuchni”, od strony starego szlafroka i rozdeptanych kapci szurającej po mieszkaniu Adelajdy Brejbiszowej, nie jest tak urzekający, jak obraz tych samych czasów, nakreślony w Godzinie pasowej róży, której akcja rozgrywa się raczej w świecie salonów (Jędrych, 2017, s. 75). 
Autorka obudowuje te rozważania ciekawymi wątkami związanymi z powstawaniem kolejnych utworów, wypowiedziami pisarki, krytyką literacką im poświęconą oraz tropami autobiograficznymi, które mogą okazać się cenne w dalszych psychologicznych i socjologicznych interpretacjach losów dziewczynek, dziewcząt i kobiet w prozie Krüger.

W rozdziale drugim, zatytułowanym Portrety, pojawiają się trzy studia: Ubrania, Odpowiednia, Matka. Pierwsze dotyczy interpretowania kondycji społecznej i psychicznej bohaterek przez pryzmat ubrań, jakie noszą. Jędrych wytycza tutaj ciekawy sposób postrzegania śladów, tropów czy sygnatur genderowych poprzez analizę strojów i kostiumów kobiet, inspirowany pracami Kłosińskiej (1999/2012) i Wójcik-Dudek (2007). Autorka pisze:

Maria Krüger [...] potrafi czynić z ubrania zdarzenie. Raz jest ono przebraniem, które jednak pełni dwojaką funkcję - niewoli lub wyzwala. Innym razem staje się znakiem statusu materialnego lub narzędziem władzy; ubieranie się i oglądanie ubrań może być także źródłem przyjemności, swego rodzaju rozrywki estetycznej. Podziwianie sukienek czy płaszczy dostarcza wtedy takich samych wzruszeń, jak podziwianie obrazów w galerii [...] (Jędrych, 2017, s. 82).

Badaczka przedstawia intrygujące interpretacje „czynienia z ubrania zdarzenia”, kiedy to kostium, strój, uniform jest wyrazem osobowości, tożsamości lub transformacji kobiecej, choć może być także przejawem stygmatyzacji albo symbolicznym gorsetem zachowań społecznych czy rodzajem specyficznej maskarady związanej z kobiecością. Co ciekawe, Lasoń-Kochańska (2012) twierdzi, że np. w Godzinie pąsowej róży „nie ma feministycznej świadomości”, a pisarka „pławi się w fetyszyzowaniu własnej kobiecości”, powtarzając „socjalistyczne hasła emancypacyjne" (s. 107). Jędrych (2017) polemizuje z tym stanowiskiem i twierdzi, że Krüger bawi się rekwizytami epoki XIX wieku, a konserwatywny sztafaż kobiecości łagodzi komizmem postaci oraz sytuacyjnym (s. 92).

Autorka omawia również sytuacje, w których bohaterki przebierają się za mężczyzn, aby móc realizować pasje lub uczyć się. I chociaż zaznacza, że maskarady te są wielokrotnie nośnikami wspomnianego przez nią komizmu, równie mocno podkreśla, że bohaterki mogą dać upust pasjom tylko wtedy, gdy udają chłopców. Kiedy bowiem zrzucają męskie kostiumy, społeczeństwo od razu przypomina im o powinnościach biologicznych oraz społecznych. $\mathrm{Z}$ analiz badaczki wynika, że strój jest istotnym społecznie rekwizytem wymuszania na kobietach ról genderowych. Szczególnie w utworach prezentujących rzeczywistość XIX wieku stanowi metaforę kobiecego zniewolenia, zbudowaną przez Krüger najpewniej przypadkiem, na tyle jednak widoczną, że można 
w jej kontekście pisać o współczesnym dyskursie wokół uprzedmiotowienia kobiety lub narzucania jej poprzez strój określonych społecznie zachowań. Warto wspomnieć, że Jędrych omawia kobiece ubrania także w odniesieniu do sygnalizowanych przez nie klas społecznych, pochodzenia bohaterek oraz ukształtowanego kulturowo przywiązania kobiet do ubrań, zamiłowania do ich nakładania, odkładnia, kupowania czy też kojarzenia stroju z jakimś inicjacyjnym zdarzeniem, np. pierwszym stosunkiem (Brygida). Badaczka podkreśla celebrowanie kobiecości przez stroje, wyrażanie ubiorem osobowości, prezentowanie swojej nowej odsłony przez bohaterki.

W drugim studium, zatytułowanym Odpowiednia, Jędrych analizuje sylwetki bohaterek jako mężatek i narzeczonych. Wynika z niego, że u Krüger przyszła małżonka musi być przede wszystkim gospodarna, mieć zamiłowanie do „krzątactwa”, lubić drobiazgowo roztrząsać, co cieszy potencjalnego małżonka, planować posiłki, robić zakupy. „Odpowiednie” powinny też ładnie i skromnie wyglądać, adekwatnie do pozycji społecznej męża. Daje się tu zaobserwować uwewnętrznione przez kobiety oko patriarchatu, co widzimy $\mathrm{w}$ sytuacjach wzajemnego oceniania się kobiet w kategorii bycia przydatną dla mężczyzn pod względem urody, zdolności kulinarnych, dbałości o dom, skromności i oszczędności. Badaczka podkreśla, że dla bohaterek talent do prowadzenia domu okazuje się zbawiennym, a zamążpójście jest „idealną ścieżką kariery, która zdejmuje z dziewcząt odpowiedzialność decydowania o sobie” (Jędrych, 2017, s. 135). O byciu „odpowiednią" świadczy w analizowanych utworach miłość do dzieci, opiekuńczość, instynkt macierzyński. Odpowiednia dziewczyna musi być piękna, lecz nie nazbyt piękna, musi potrafić spojrzeć na siebie oczami mężczyzn i innych kobiet. Jędrych pisze, że dla współczesnych odbiorczyń takie propozycje kobiecości mogą być anachroniczne lub reprezentować stereotypy płciowe. Termin „odpowiednia” odnosi się tu do tytułu powieści Krüger, Odpowiedniej dziewczyny, nasuwa jednak karykaturalne i wyolbrzymione - choć w kontekście przywołanych na początku przez badaczkę dyskursów genderowych i krytyki feministycznej istotne - skojarzenie z kultową figurą „podręcznej” wywiedzioną z dystopijnej Opowieści podręcznej Margaret Atwood (1985/1992). Obserwujemy tu uprzedmiotowienie kobiet, odebranie im wszelkich praw, sprowadzenie ról kobiecych do zadań prokreacyjnych wbrew ich woli i pragnieniom. Nie czynię zarzutu autorce za brak tego rodzaju, wyrażonego wprost odwołania, pragnę jedynie zauważyć, że w refleksji feministycznej droga od „odpowiedniej” do "podręcznej” jest bardzo krótka. Sądzę natomiast, że prowadzone tu analizy mogłyby być przez Jędrych mocniej osadzone w dyskursach feministycznych, tak aby krytycznie podejść do cech przypisywanych „odpowiedniej” oraz objąć namysłem 
genderową świadomość Krüger, której powieści dla dziewcząt zdecydowanie pogłębiają stereotypy płciowe. Autorka rozważania w tym zakresie konkluduje asekuracyjnie, choć wcześniej wyraźnie pisze o inspirowaniu się myślą feministyczną i odważną monografią Kłosińskiej (1999/2012):

Odpowiednia dziewczyna, czy to w XIX, czy XX wieku, nie zwleka z podjęciem decyzji o małżeństwie. Takie rozwiązanie fabularne jest oczywiście zgodne ze schematem powieści pensjonarskiej, jednak trochę szkoda, że Maria Krüger, portretując swoje bohaterki jako dziewczyny niezbyt pewne siebie, ale jednak posiadające jakieś talenty, nie pozwoliła im na samodzielny rozwój (Jędrych, 2017, s. 141).

\section{Dodatkowo stwierdza:}

W powieściach dla dziewcząt Marii Krüger bohaterki zostają matkami, nie zachodząc w ciążę. W opowieściach o ich losach dostrzegamy delikatne pęknięcie - na temat tego, co po ślubie, w sypialni, na oddziale położniczym - nie mówi się, nawet nie myśli, mimo tego dziewczęta rozmyślają o przyszłych mężach, snują uładzone marzenia o przyszłym życiu (Jędrych, 2017, s. 159).

Studium trzecie, Matka, poświęcone zostało macierzyństwu. Co ciekawe, badaczka podkreśla, że podtrzymywane przez pisarkę w powieściach dla dziewcząt stereotypy płciowe, również te związane z obrazem matki, inaczej rozpatrywane są przez nią w utworach skierowanych do odbiorczyń dorosłych, Brygidzie i Gorzkim winie. Podczas gdy repertuar doświadczeń i emocji kobiecych wybrzmiewa silnie w powieściach dla starszych czytelniczek, w androcentryczny subgatunek wpisane jest protekcjonalne traktowanie przeżyć dziewczęcych. Daje się odczuć niedosyt szczerego pisania o płci w powieściach dla dziewcząt u Krüger, co wynika, jak wnoszę po rozpoznaniach dokonanych przez badaczkę, z ograniczeń, jakie narzuca pisarkom omawiana konwencja i poddanie się w mniejszym lub większym stopniu jej niewolniczym wyznacznikom. Warto nadmienić, że ciekawe byłoby stworzenie studium o opresyjności tego subgatunku, żywotności i przeobrażeniach zachodzących na jego gruncie. Rodzą się ogólne pytania, na ile zaznaczona przez Jędrych we Wstępie formuła powieści dziewczęcej, zastępującej dawną powieść dla dziewcząt, odpowiada współczesnym potrzebom feministycznego reinterpretowania doświadczeń dziewczynek, dziewcząt, kobiet? Czy jest w stanie sprostać nowym strategiom narracyjnym, m.in. herstorytellingowi? Na ile zrzuciła $z$ siebie piętno androcentryzmu i w jaki sposób demontuje lub wymienia jego wyznaczniki, by być narracją, dzięki której wybrzmiewają dyskursy feministyczne i genderowe? 
W ostatnim studium najciekawsze okazują się portrety matek w powieściach dla kobiet. Analizując Brygidę i Gorzkie wino, Jędrych znakomicie przedstawia toksyczne relacje pomiędzy matkami a córkami, fizyczną i psychiczną przemoc między kobietami, powielanie przez córki trudnych biografii matek, zazdrość matek o córki, a nawet nienawiść matki do córki i odwrotnie. Autorka wybiera z obu powieści intrygujące cytaty, obnażające rozpad więzi w linii matrylinearnej oraz społeczne funkcjonowanie niekochanych córek, przerażonych obecnością matek w ich życiu, zakompleksionych, straumatyzowanych tą pierwotną relacją z osobą najbliższą, czasami wrogą, destrukcyjną, której córka życzy śmierci. Te oryginalne i bardzo interesujące interpretacje Jędrych podpiera psychoanalizą Brunona Bettelheima (1977/1996), a także pracami Grażyny Borkowskiej (1996), Hélène Cixous (1975/1993), Luce Irigaray (1977/2000) oraz Pierre’a Péju (1981/2008). Ciekawe byłyby tu również nawiązania do prac Zrodzone $z$ kobiety. Macierzyństwo jako doświadczenie i instytucja Adrienne Rich (1976/2000) i Historia miłości macierzyńskiej Élisabeth Badinter (1980/1998).

Jędrych przywołuje też bezradne, infantylne postaci mężczyzn, niepotrafiących być partnerami, ojcami, lekkoduchów, podporządkowanych decyzjom rozkochanych w nich matek. Pojawia się temat przedwczesnego macierzyństwa, bohaterkom podrzucane są bowiem niemowlęta, którymi się zajmują, choć same są jeszcze dziećmi. Do ważnych wątków należy pragnienie bycia matką, chęć posiadania dziecka, kompetencje dziewcząt do niańczenia cudzych dzieci, czasami bezwzględne oddanie się im, co wymaga od bohaterek wyrzeczenia się pasji lub marzeń o samodzielności. W tych powieściach dla dziewcząt najważniejsze okazuje się być dobrą panią domu, która koordynuje prywatną przestrzeń, sferę publiczną postrzegając jako domenę mężczyzn - mądrzejszych, przedsiębiorczych - którym potrzebne są skromne i zaradne kobiety. Zamiast trudnej wędrówki inicjacyjnej i walki o samą siebie, w omawianych utworach dla nastolatek liczy się szybka decyzja o małżeństwie, tak jakby było ono jedynym bastionem bezpieczeństwa, ale też, co podkreśla badaczka, wybawieniem przed realizacją pasji, co do których młode bohaterki wcale nie są przekonane. "Odpowiednie” szukają dla siebie niszy domowej, są zbyt słabe, by realizować kiełkujące w nich pasje i budować swój kapitał kulturowy, dlatego ich punktem odniesienia stają się mężowie.

W Zakończeniu badaczka ogólnie zarysowuje tropy biograficzne, które odnaleźć można w twórczości Krüger. Być może materiał ten jest zapowiedzią dalszych badań Jędrych nie tylko nad prozą pisarki, lecz także nad jej biografią. Reasumując rozważania o portretach dziewczynek, dziewcząt, kobiet w twórczości Krüger, autorka stwierdza: 
Analizując i interpretując sposób życia, dokonywane wybory, marzenia, relacje z innymi ludźmi, powtarzalność zachowań bohaterek Krüger, w pewnym momencie doszłam do wniosku, że „moja” autorka pisała nie o dziewczynkach, dziewczynach i kobietach, ale o jednej kobiecie, w której żyją wszystkie trzy etapy - młoda, dojrzała i stara. Co więcej, sformułowaniem, które lepiej oddaje to, co w swoich książkach robi Krüger jest nie pisanie o kobiecie, a pisanie kobiety - analogicznie do szkicowania lub malowania portretu (Jędrych, 2017, s. 179).

Monografia Jędrych jest oryginalną i ciekawą propozycją badawczą, którą sytuować można między pisaniem o kobietach, czyli interpretacyjnym portretowaniem dziewczynek, dziewcząt, kobiet $\mathrm{w}$ kolejnych powieściach pisarki i ich doświadczeń scentralizowanych w ramach określonego subgatunku, a „pisaniem kobiety”, możliwym do zaobserwowania w analizach badaczki poświęconych powieściom dla kobiet. W nich rzeczywiście zarówno Krüger jako pisarce, jak i Jędrych jako badaczce udała się owa trudna sztuka nazywana przez autorkę "pisaniem kobiety”. Dzięki metodologii feministycznej i genderowej badaczka z powodzeniem namalowała portret dziewczynki, dziewczyny, kobiety - tej najpierw dojrzewającej, potem noszącej bagaż doświadczeń życiowych, w który wpisują się traumy dziecięce wynikające m.in. z trudnych relacji z matką; niespełnione miłości; skrajne emocje: euforyczne, ale i negatywne, sprawiające, że widzimy obraz kobiety mocno pokiereszowanej przez życie, uciekającej przed nim w imaginacyjne światy. „Pisanie kobiety” możemy rozumieć u Jędrych jako wielowymiarową herstorię pozbawioną jednoznacznego happy endu, w której liczą się skazy, rany, blizny, impresje o smutku i szczęściu oraz tęsknota za spełnieniem.

Opracowanie Jędrych jest ciekawą lekturą - przynosi wiele nowatorskich rozpoznań twórczości pisarki, a także wytycza nowe kierunki badań nad tą prozą lub pisarstwem kobiet tworzących podobnie do Krüger, których utwory dla dziewcząt i kobiet wymagają rzetelnego opisu z perspektywy feminizmów. Wydaje się bowiem, że tylko krytyczne odczytania literatury skierowanej do dziewcząt, osadzone w nowych metodologiach, są w stanie dać jej drugie życie i wyjaśnić współczesnym czytelnikom/czytelniczkom fenomen dawnej popularności tego subgatunku, postrzeganego dziś często jako anachroniczny i operujący przebrzmiałym sztafażem dziewczęcości/kobiecości. 


\section{Bibliografia}

Atwood, M. (1992). Opowieść podręcznej (Z. Uhrynowska-Hanasz, tłum.). Warszawa: PIW. (wyd. oryg. 1985).

Bachelard, G. (1975). Wyobraźnia poetycka. Wybór pism (H. Chudak, tłum.). Warszawa: PIW. (wyd. oryg. 1960).

Badinter, E. (1998). Historia miłości macierzyńskiej (K. Choiński, tłum.). Warszawa: Oficyna Wydawnicza Volumen, Liga Republikańska. (wyd. oryg. 1980).

Baluch, A. (2008). Od form prostych do arcydzieła. Wykłady, prezentacje, notatki, przemyślenia o literaturze dla dzieci i młodzieży. Kraków: WN UP.

Bettelheim, B. (1996). Cudowne i pożyteczne. O znaczeniach $i$ wartościach baśni (D. Danek, tłum.). Warszawa: W.A.B. (wyd. oryg. 1977).

Brach-Czaina, J. (1999). Szczeliny istnienia. Kraków: eFKa. (wyd. oryg. 1992).

Cixous, H. (1993). Śmiech Meduzy (A. Nasiłowska, tłum.). Teksty Drugie. Teoria literatury, krytyka, interpretacja, 4/5/6(22/23/24), 147-166. (wyd. oryg. 1975).

Domańska, E. (1999). Mikrohistorie. Spotkania w międzyświatach. Poznań: Wydawnictwo Poznańskie.

Graban-Pomirska, M. (2006). Szkoła narzeczonych. O powieści dla dziewcząt w dwudziestoleciu międzywojennym. Gdańsk: Wydawnictwo UG.

Irigaray, L. (2000). Ciało w ciało z matka (A. Araszkiewicz, tłum.). Kraków: eFKa. (wyd. oryg. 1977).

Janion, M. (1991). Projekt krytyki fantazmatycznej. Szkice o egzystencji ludzi i duchów. Warszawa: Wydawnictwo PEN.

Jędrych, K. (2017). Portret dziewczynki, dziewczyny i kobiety w powieściach Marii Krüger. Katowice: Wydawnictwo UŚ.

Kłosińska, K. (1999). Ciało, pożadanie, ubranie. O wczesnych powieściach Gabrieli Zapolskiej. Kraków: eFKa.

Krüger, M. (1945). Szkoła narzeczonych. Warszawa: Wydawnictwo E. Kuthana.

Krüger, M. (1960). Godzina pąsowej róży. Warszawa: Iskry.

Krüger, M. (1962). Klimek i Klementynka. Warszawa: Nasza Księgarnia.

Krüger, M. (1970). Brygida. Warszawa: Czytelnik.

Krüger, M. (1975a). Gorzkie wino. Warszawa: Czytelnik.

Krüger, M., Bielińska, H. (1975b). Petra. Warszawa: Iskry. (wyd. oryg. 1957).

Krüger, M. (1980). Po prostu Lucynka P. Warszawa: Iskry.

Krüger, M. (1988). Odpowiednia dziewczyna. Warszawa: Iskry.

Kruszewska-Kudelska, A. (1972). Polskie powieści dla dziewcząt po roku 1945. Wrocław: Zakład Narodowy im. Ossolińskich.

Kruszyńska, E. (2009). Dydaktyczny charakter powieści dla dziewcząt w dwudziestoleciu międzywojennym. Toruń: WN Grado. 
Lasoń-Kochańska, G. (2012). Gender w literaturze dla dzieci i młodzieży. Wzorce płciowe i kobiecy repertuar topiczny. Słupsk: WN AP.

Péju, P. (2008). Dziewczynka w baśniowym lesie. O poetykę baśni: w odpowiedzi na interpretacje psychoanalityczne i formalistyczne (M. Pluta, tłum.). Warszawa: Sic!. (wyd. oryg. 1981).

Rich, A. (2000). Zrodzone z kobiety. Macierzyństwo jako doświadczenie i instytucja (J. Mizielińska, tłum.). Warszawa: Sic!. (wyd. oryg. 1976).

Wójcik-Dudek, M. (2007). Strój i dziewczyna. O powieści dla dziewcząt. Świat i słowo, 1, 201-213.

Wójcik-Dudek, M. (2008). Czytająca dziewczyna. O przemianach współczesnej powieści dla dziewcząt. W: K. Heska-Kwaśniewicz (red.), Literatura dla dzieci i młodzieży (po roku 1980) (t. 1, s. 158-179). Katowice: Wydawnictwo UŚ. 